\title{
Transgenerational Trauma and Cyclical Haunting in Pat Barker's Regeneration Trilogy
}

\author{
MeERA AtKInson
}

UNIVERSITY OF TECHNOLOGY, SYDNEY

-INTRODUCTION

Pat Barker's Regeneration Trilogy, made up of the three novels Regeneration, The Eye in the Door and The Ghost Road, has long been held a classic of English literature and an important rendering of the trauma of the Great War. ${ }^{1}$ What has been less discussed is the way the trilogy works as a comprehensive depiction of the cyclical affects/effects of familial trauma and war. This article examines the novels as a literary testimony of transgenerational trauma and its transmissions with a focus on the cyclical operations of 'traumatic affect' as affect that is bound to, and by, trauma. Drawing on Deleuze's and Massumi's ideas on affect, virtuality and autonomy in relation to Derrida's conception of hauntology, and touching on Laplanche's psychoanalytic view of trauma as a kind of ontological condition, I argue that the conjunction of these divergent theoretical strands enables exploration of the

\section{ISSN 1837-8692}

Cultural Studies Review 2015. @ 2015 Meera Atkinson. This is an Open Access article distributed under the terms of the Creative Commons Attribution 4.0 Unported (CC BY 4.0) License (https://creativecommons.org/licenses/by/4.0/), allowing third parties to copy and redistribute the material in any medium or format and to remix, transform, and build upon the material for any purpose, even commercially, provided the original work is properly cited and states its license. 
autonomy of traumatic affect, allowing trauma to be contemplated as a structural force that troubles imagined notions of subjective experience as confined to an individual body. Barker's portrayal of trauma as a structural force in her otherwise seemingly conventional text is profound in that it reveals the way historic traumatic affect feeds into subjective and familial experience, and in turn plays out past these interpersonal realms to enact and transmit trauma in networks beyond.

It is a notable detail that the early explorations of trauma by pioneering psychoanalysts were advanced by Sigmund Freud in the wake of World War I, when the men Barker would later research and characterise returned from Europe with horrific injuries and debilitating 'shell shock'. Freud's work at that time popularised the basic understanding of psychic trauma that remains in play today. Situating trauma within his theory of the unconscious, Freud considered it in economic terms, describing it as 'an experience which within a short period of time presents the mind with an increase of stimulus too powerful to be dealt with or worked off in the normal way', the subsequent result being 'permanent disturbances of the manner in which the energy operates'. ${ }^{2}$ Since then, this formative psychoanalytic perception of trauma has been developed upon in various ways and disciplines, but it is Laplanche's engagement with affect as the bodily (and relational) representative of trauma that most facilitates my exploration of the autonomous force of traumatic affect as exceeding individual bodies. ${ }^{3}$ But before moving on to focus on the novels, I will briefly outline the key terms that inform my interpretation.

\section{-SPECTRALITY, AFFECT AND AUTONOMY}

Discussing the 'phenomenality of the political' in Specters of Marx, Derrida refers to an element of public life that is 'neither living nor dead, present nor absent', making the claim that such an element is that which 'spectralises'. ${ }^{4}$ Derrida uses the word 'hauntology' to supplant ontology. With it, he seeks not to explore 'the priority of being and presence' but to posit the figure of the ghost as 'that which is neither present nor absent, neither dead nor alive' and as a site of vacillating certainty and possibility. As Colin Davis makes clear in his essay, 'Hauntology, Spectres and Phantoms', which contrasts Derrida's notion of the 'spectre' and Abraham and Torok's concept of the 'phantom', Derrida's hauntology 'has nothing to do with whether or not one believes in ghosts' and 'it does not belong to the order of 
knowledge. ${ }^{5}$ Derrida's hauntology casts into doubt the notion of a 'reassuring order of presents' and the border between the 'actual or present reality of the present, and everything that can be opposed to it: absence, non-presence, non-effectivity, inactuality, virtuality, or even simulacrum in general'.6 In other words, hauntology speaks to the questionable solidity of what we think of as the present. Though Derrida's writing on hauntology doesn't explicitly feature affect, it does imply it.

'Affect theory', as a polysemic, multidisciplinary and often interdisciplinary field, comprises affect in many definitions and theoretical configurations. I understand affect to be a biological and energetic response inherent to all sentient beings (the systems and expressions of which may differ between species) and more poetically, as Gregg and Seigworth, put it, 'the passage (and the duration of passage) of forces or intensities' and the 'visceral forces beneath, alongside, or generally other than conscious knowing, vital forces insisting beyond emotion'.7

The autonomy of affect, as theorised by Deleuze and Massumi, is an understanding of affect as escaping subjective containment in virtuality operative beyond particular bodies. ${ }^{8}$ As I aim to show, when Derrida's notion of the virtual/simulacrum as spectral is given a Deleuzian inflection, Derrida's virtual lends itself to speculation as the space in which trans-trauma occurs at all points and levels of assemblage. Also compelling about this view of affect is the positing of affects as virtual synaesthetic perspectives anchored in what embodies them, and its potential for thinking about the blending of sensual modes of transmission, that is, contagion via smell, language, tone, vision, touch and so on. So it is that Deleuze and Massumi's work on the autonomy of affect resonates with the Derridian spectre. The very notion of 'autonomy of affect' and 'virtuality' conjures up visions of ghostliness. Though they represent distinct and different philosophical and ontological positions, both theories bring to mind a plane beyond that of the flesh and outside what can be seen with the naked eye, but which nevertheless might still encompass the flesh and the eye as well as the emotion registered by the flesh and evident in the eye. How might the spectre be felt or marked if not through affect and language?

\section{- REgEnERATION AS HAUnTOLOGICAL TEXT}

The Regeneration Trilogy is not pointedly 'experimental' and it is not memoir (though it is painstakingly researched and peopled by a mix of fictional and real-life 
historic characters). Its prose is in the main orthodox, if skilfully crafted, and its narrative is cleverly structured without being emphatically traumatic. Or rather, I should say that the question of whether or not the trilogy structurally embodies a traumatic temporality is an interesting one that deserves more attention than I can give it in this article. The multiple narratives in the novels do move back and forth across time, but the text doesn't dramatically reveal, at a structural level, what Cathy Caruth calls the 'delayed appearance' and 'belated address' of trauma, thereby mirroring the unpredictable and repetitious temporality of traumatic memory in the same highly innovative way, for example, as Resnais's cinematic masterpiece, Hiroshima, Mon Amour, based on the Marguerite Duras screenplay, or Duras's novel The Lover, which alternates between first and third person, present and past tense, creating subjective shifts of intimacy and distance, in which time precedes in a nonlinear manner capable of crossing continents, seas, decades and narrator selves. ${ }^{9}$

Instead, Barker's trilogy cunningly demonstrates the poetics of trans-trauma by means of a subtle yet insightful cultural exposé. The novels testify to the trauma of masculinity on a number of levels: masculinity as traumatised, masculinity as traumatic and masculinity as traumatising. The trilogy has been much praised for its description of the trauma of World War I, and rightly so, but it is a more multilayered representation of trauma than has previously been acknowledged. Though it is revered as among the finest works of literature about war trauma, less observed is the way Barker reveals the multi-generational familial transmission of trauma at the heart of war. As I aim to show, the trilogy translates a complex web of personal, cultural, national and global trauma, and as such it is a creative portrayal of cyclical haunting that shows how the autonomy of traumatic affect circulates in and between assemblages.

The transmission of trauma and affect are evident everywhere in Barker's three books. Billy Prior, the cynical, damaged and damaging protagonist, was troubled and traumatised well before he went to war. Sexually assaulted by a priest as a child, he acts out of trauma throughout his life through a propensity for sexual addiction and sexual violence. He grew up witnessing domestic violence and was emotionally abused by his father. The Eye in the Door, the second in the series, gives most focus to Prior's familial history. It also attends to the inner experience of traumatised soldiers in the messed-up climate of 'home'. The two themes converge in a striking 
scene in which Prior visits his hometown in an effort to help Beattie, an old family friend and objector unjustly jailed. Staying with his parents, Prior is confronted with the childhood memory of chanting 'PIG PIG PIG' to himself and punching his fist into his other hand on the steps overlooking the lounge room while witnessing his drunk father beating his mother. Barker writes:

Obviously, his present attempt to understand his parents' marriage was more mature, more adult, more perceptive, more sensitive, more insightful, more almost anything you cared to mention, than PIG PIG PIG PIG, but it didn't content him, because it was also a lie: a way of claiming to be 'above the battle'. And he was not above it: he was its product. He and she-elemental forces, almost devoid of personal characteristics-clawed each other in every cell of his body, and would so until he died.10

This moment is, in a sense, the beating heart of the trilogy. Here Barker suggests that this is what calls war into being, the 'lie', the 'claiming to be above the battle' of facing and addressing individual and collective trauma, and that dooms us to acting it out. For all the terrible, unspeakable, unimaginable horror witnessed and experienced in France this image of his parents clawing each other in every cell of his body till the day he dies is perhaps the most horrific of all. And later in The Eye in the Door, the link between Prior's war and childhood trauma is made even more overtly when he starts to dissociate into an alter personality and Rivers, his psychologist, makes the connection and observation that this traumatic splitting didn't begin in France as the alter claimed, but way back in the time of PIG, and that it was an existing subjective splitting that was triggered and intensified by a particularly traumatic war event. Even supposedly 'normal' characters in the trilogy embody transgenerational trauma. Rivers, the anthropologist/'shell shock' doctor who features in all three novels, treating the men returning shattered from the trenches, is also disturbed, having been traumatised by his father at the age of four; beaten for crying during a haircut before being shown a portrait of an ancestor of the same name, who had withstood the amputation of a leg with no anesthetic without making a sound, as an example of manhood.

The transmission of trauma and autonomy of affect, then, challenge the boundary between the past and present, and the very presumption of a reliably discernable distinction in Barker's trilogy, even though the past and the present are, 
in a literary sense, apparently clearly demarcated. Hence the Regeneration Trilogy is a hauntological text in which Barker channels a generation long past. The process of writing cyclical haunting might be viewed as the conjuring of an intensity-rich and particularly atmospheric environment in which the autonomy of spectral affect is virtual and anchored in the materiality of writer, text and reader. Further, the autonomy of affect is a productive way to think about the dynamism of traumatic affect in assemblage, allowing as it does acknowledgment of affective movements within culture. In 'The Autonomy of Affect', Massumi writes:

The autonomy of affect is its participation in the virtual. Its autonomy is its openness. Affect is autonomous to the degree to which it escapes confinement in the particular body whose vitality, or potential for interaction, it is. Formed, qualified, situated perceptions and cognitions fulfilling functions of actual connection or blockage, are the capture and closure of affect. Emotion is the intensest (most contracted) expression of that capture-and of the fact that something has always and again escaped. ${ }^{11}$

If this is considered in relation to De Landa's theory of assemblage, a sense of trauma and traumatic affect as a social force becomes palpable. Currents of traumatic affect are transmitted autonomously between assemblages, such as families, organisations, nations and wars, and they play a part in the formation of such assemblages.

\section{-AfFECT AND ASSEMBLAGE}

There is, unsurprisingly, a strong germinal connection between the notions of affect, autonomy and assemblage. Deleuze and Guattari's A Thousand Plateaus was the inspiration for Manual De Landa's assemblage/network theory. ${ }^{12}$ De Landa begins by outlining Deleuze and Guattari's framing of assemblage and the historical processes that create and stabilise 'a wide variety of wholes constructed from heterogeneous parts'.13 Noting that Deleuze and Guattari only focused on the idea of assemblage for a few pages in A Thousand Plateaus, hardly constituting a theory proper, De Landa maintains that the concepts used to describe the characteristics of assemblages in those few pages, such as 'territorialisation' are 'highly elaborated' 
throughout the body of work. ${ }^{14}$ De Landa goes on to cast his understanding of assemblages as:

being wholes whose properties emerge from the interactions between parts, can be used to model any of these intermediate entities: interpersonal networks and institutional organizations are assemblages of people; social justice movements are assemblages of several networked communities; central governments are assemblages of several organizations; cities are assemblages of people, networks, organizations, as well as of a variety of infrastructural components, from buildings and streets to conduits for matter and energy flows; nation-states are assemblages of cities, the geographical regions organized by cities, and the provinces that several such regions form. ${ }^{15}$

Assemblage (or network) theory makes possible an alternative model of social ontology to traditional individual/social and personal/political dichotomies. In basic terms, De Landa's neo-assemblage theory rejects both essentialism and social constructivism in addressing the problem of the link between the micro-and the macro-levels of social reality'.16 He claims: 'Entities ranging from atoms and molecules to biological organisms, species and ecosystems may be usefully treated as assemblages and therefore as entities that are products of historical processes', 17 and he insists assemblage theory can be applied to 'social entities',18 Furthermore, De Landa states: 'This theory must, first of all, account for the synthesis of the properties of a whole not reducible to its parts ... In other words, unlike organic totalities, the parts of an assemblage do not form a seamless whole'.19

This has implications for the fields of trauma and affect, and specifically transgenerational transmission within and beyond the family. Considering the properties emerging from the interactions between parts as being traumatic affect, that is, affect bound to trauma, might then suggest their transmitting in an autonomous manner. Viewing trauma in relation to autonomous traumatic affect and assemblage avoids solipsistic tendencies in thinking trauma, and the abstraction of affect and trauma, and locates the poetics of trans-trauma in lived individual and social experience.

Among affect theorists such as Denise Riley and Teresa Brennan, and of course Deleuze and Massumi, affective autonomy and transmission is hinted at as 
everything from a kind of subjective demonic possession to an impersonal cosmic dance. ${ }^{20}$ I take the position that the autonomy of affect operates on a number of levels and in a number of ways that make dispirited theoretical views of it useful. For example, Riley says that the 'stance that insists on language as an instrument of willed control glosses over its directing rawness', going on to describe the way the raging speaker [a common mode of familial transmission] is not himself/herself speaking so much as being spoken by rageful affect. ${ }^{21}$ Obviously, most people don't set out to abuse and traumatise each other. Many parents unwittingly transmit traumatic affect to their children, more or less unconsciously, or on a consciousunconscious continuum, and even where there is consciousness or apparent intent, the force of traumatically driven affect can make responsible personal choice difficult, if not impossible.

If we accept this and consider the possibility that trauma and its transmission can function somewhat independently of an agent, it becomes evident that trauma, as the restless site of a denied subjective/collective splitting/death, gives rise to all manner of deathly processes, such as addictions (including process addictions, such as work and gambling), suicide, all forms of child and animal abuse, misogyny and violence against women, homophobic violence, racism, ruthless capitalism and irresponsible corporatism, and a host of other obsessive, compulsive and destructive behaviours. To my mind, it is akin to what twelve-step recovery programs, such as Alcoholics Anonymous, refer to as the 'disease'. It is at worst a malevolent force and at best an insidious one, constantly disturbed and disturbing. It is the Moloch in 'HOWL', savaging the best minds of Ginsberg's generation, heralded by him as the death within life that has the potential for rebirth and reincarnation: 'Wake up in Moloch! Light streaming out of the sky!'22

The autonomy of traumatic affect rumbles, spills, bursts forth, erupts, leaks, emits, fumes, whispers, screams and acts from its restless grave, because at the deepest level it seeks recognition. It demands witnessing and memorial and it haunts until it gets it. It is the crime (or imagined crime) that wants to get caught, the perpetual cry for help that plugs its ears to the sound of its own cry. Every time it appears, in any form, every time it is transmitted, in any way, to any degree, it is begging for 'living attention', which means, for Brennan, something like a cross between love, the life drive, and what she terms 'discernment', described as the 
'considered sensing (by smell, or listening, as well as observation)' and 'the process of feeling that also operates, or seems to operate, as the gateway to emotional response.'23 The transmission of traumatic affect takes place with routine and endemic gravity, often with serious consequences, and that is why the poetics of trans-trauma is so vital an intervention. In its concentration on familial transmission and cultural operations and its revelation of trauma as a structural force, such literature hails from the most intimate areas and relations of our lives and personal experience while extending well beyond to encompass cultural and collective history.

Barker's trilogy makes clear who among us, in terms of lived individual and social experience, is most vulnerable to the transmission of traumatic affect and the violence often associated with it. Another of Prior's most haunting childhood memories involves walking near the cattle pens while cattle were being driven to slaughter and finding that a cow had broken loose and was following him:

He backed away from the noise and commotion, ran up a back alley between the high dark walls, then realized that, as in a nightmare, a cow was following him, with slithering feet and staring eyes, and men chasing after her. More men came running from the other end of the alley. They cornered her, closing in from both sides, and the terrified animal slipped in her own green shit and fell, and they threw heavy black nets around her and dragged her back to the herd, while all along the alley housewives whose clean washing had been swept aside erupted from their backyards, shouting and waving their arms ... The sight of the cow in the net stayed with him. Many a night he dreamt about her and woke to lie staring into the swirling darkness. ${ }^{24}$

This passage evocatively conveys the tragedy of trauma under the oppressive assemblage of capitalist patriarchy, in which non-human animals, children, women, the socially disadvantaged, the disabled and aged, and those discriminated against by race and sexual or gender orientation, are the most vulnerable to traumatic transmission. Barker's description of the real-life scene as 'as in a nightmare' hints at the way the event becomes, for the young boy, a recurring nightmare, a representation perhaps of all the trauma, injustice and powerlessness he witnesses 
and experiences all around him. Tragically, this does not prevent Prior from himself becoming an actor in capitalist patriarchal oppression.

\section{-STRUCTURAL/HISTORIC/HISTORIC TRAUMA}

Thinking about trans-traumatic assemblage also calls for consideration of two significant notions of trauma referred to as 'structural' and 'historical'. Psychoanalytic theorist Jean Laplanche offers a productive model for conceiving structural trauma and its transmission. In his introduction to Laplanche's essays, John Fletcher discusses Laplanche's theory of 'primal seduction' as describing unconscious material transmitted by the $[\mathrm{m}]$ other as undergoing a kind of metabolic process in which transmitted material is absorbed, digested or undigested and in the process broken down into some refigured entity. This process results not only in 'specific pathological formations', but in 'the construction of the unconscious and the psychical apparatus in general'.25 In other words, for Laplanche, the formation of subjectivity is itself a traumatic operation that depends upon familial transmission. Laplanche also seems to hold that there is no affect in the unconscious, and that enigmatic messages operate as unrepresentative and thing-like, or as internal foreign bodies'.26 However, this assertion that affect is not operative in the unconscious does not amount to a dismissal of affect. In his essay 'A Short Treatise on the Unconscious', Laplanche describes affect as the manner in which the ego and body are affected and that therefore affect is the way in which the unconscious speaks itself in the body via the ego. Thus, he insists he is merely relocating affect topographically, rather than ruling it out of trauma transmission. ${ }^{27}$

In contrast, 'historical' trauma might be thought to function in two ways: firstly, as trauma that comes to pass in the life of the subject after the formative motherchild transmission has taken place, that is, trauma experienced in environment, nurture and culture, and secondly as collective traumatic experience of historical import such as war or ecological extremity, which I denote by way of a capital $\mathrm{H}$. Dominick LaCapra addresses both in his examination of notions of objectivity and constructivism in the writings of critical historians. Arguing for a distinction between structural and Historical trauma, LaCapra contends they involve differing modes of mourning and challenges to writing, positing structural trauma as, 'transhistorical absence (absence of/at the origin) and appears in different ways in 
all societies and all lives'. ${ }^{28} \mathrm{He}$ also describes it as 'separation from the (m)other', 'the passage from nature to culture', 'the entry into language', and 'the constitutive nature of originary melancholic loss in relation to subjectivity'. ${ }^{29}$

Historic trauma, as epitomised by the Holocaust, is for LaCapra 'specific and not everyone is subject to it or entitled to the subject-position associated with it'. ${ }^{30}$ This creates an ethical dilemma for those writing about it, with unavoidable temptations to problematic empathetic and subjective identifications an inevitable pitfall. In conclusion LaCapra writes:

One may even argue that it is ethically and politically dubious to believe that one can overcome or transcend structural trauma or constitutive absence to achieve full intactness, wholeness, or communal identity and that attempts at transcendence or salvation may lead to the demonization and scapegoating of those on whom unavoidable anxiety is projected. But $[\mathrm{H}]$ istorical traumas and losses may conceivably be avoided and their legacies to some viable extent worked through both in order to allow a less self-deceptive confrontation with transhistorical, structural trauma and in order to further historical, social, and political specificity, including the elaboration of more desirable social and political institutions and practices. $^{31}$

If The Eye in the Door most embodies structural and small h historical trauma, Regeneration, the first in the series, best illustrates capital H Historical trauma, presenting a powerful and well-rounded account of British men during World War I. Focusing on the relationship between Rivers and Sassoon, the poet and anti-war protester, with Prior as a lesser but still significant character, it features many distressing scenes that zero in on the often insurmountable challenge of attempting to work through trauma that is frequently a combination of structural, historic and Historic trauma. It highlights ill-conceived medical and psychiatric attempts to treat trauma and the very real potential of their resulting in further traumatisation in the problematic quest for a 'cure', as is the case in a scene in which a patient is tortured by a doctor whose brutal methods differ from those of Rivers. Yealland, witnessed by a mortified Rivers, applies electric shocks and verbal abuse until the mute patient talks. Barker writes: 'Rivers had felt that he was witnessing the silencing of a human being. Indeed, Yealland had come very close to saying just that. "You must speak, but 
I shall not listen to anything you have to say."'32 Rivers, it turns out, is not only shocked by Yealland's extreme methods, but also unsettled about the nature of his own, though these are undoubtedly more benign. Barker continues:

Just as Yealland silenced the unconscious protest of his patients by removing the paralysis, the deafness, the blindness, the muteness that stood between them and the war, so, in an infinitely more gentle way, he [Rivers] silenced his patients; for the stammerings, the nightmares, the tremors, the memory lapses, of officers were just as much unwitting protest as the grosser maladies of the men. ${ }^{33}$

Being a good man, conscience of his ethical duties, Rivers is torn between his desire to help the men and serve his country in its hour of need and his doubts about the war and the reality of what serving his country actually means. In plain terms, Rivers' task is to render the stricken soldiers functional so that they can be returned to the trenches for further traumatisation: 'His patients might be encouraged to acknowledge their fears, their horror of the war-but they were still expected to do their duty and return to France.'34

And so, the cycle continues well beyond the point where Barker stops writing. The men who ultimately survive the war return home unspeakably traumatised, expected to resume civilian duties and to provide for the families they make with the women left behind, many of whom have also been devastated by bomb raids, economic hardship and the loss of fathers, brothers, partners and friends. Thus, in due course, the structural/historical/Historical divisions previously noted are collapsed or, rather, the usefulness of distinguishing between them is affirmed ahead of the recognition that they inevitably cross over into one another. Cyclical haunting describes a spectral cycle in which the big picture Historical trauma of patriarchy, with its political, religious, racial, gendered and speciesed violence and oppression, as visited upon an individual life or certain culture, feeds into and out of formative and subjectively historical trauma, generating an impossible-to-categorise state of flux between bodies within any given assemblage.

In a case of the proverbial chicken and egg dilemma, historical/Historical trauma is transmitted to, and within, families and this is in turn transmitted and acted out beyond the family in social and historical contexts and relations-not in some linear, cause and effect, predictable fashion, but in myriad, chaotic, continual 
and often imperceptible movements of circulating affect. The feedback loop of traumatic affect shapes subjectivity and, by extension, family and culture, which shapes subjectivity-in tension and relentless dynamic with the positive and transformative power of love and 'living attention'.35 How, then, might a text embody this collapse? According to Massumi:

Ideas about cultural or social construction have dead-ended because they have insisted on bracketing the nature of the process. If you elide nature, you miss the becoming of culture, its emergence (not to mention the history of matter). You miss the continuum of interlinkage, feed-forward and feedback, by which movements capture and convert each other to many ends, old, new, and innumerable. ${ }^{36}$

If we think here of nature as including affect, cyclical haunting may be seen as a continuum of interlinkages between traumatised subjects and the broader culture they inhabit, of networks of feeding-forward and feeding-back, by which 'movements capture and convert each other to many ends, old, new, and innumerable'. The concept of cyclical haunting enables consideration of the ways trans-trauma might function socially, and even independently of an agent, making it possible to broaden and deepen the connection between trauma, affect and writing. The idea of trauma functioning socially may seem counter-intuitive given the way trauma is so routinely figured as resisting representation and the fact that subjects who suffer from post traumatic stress so often struggle to communicate their experience to those around them, or even to conceive of it satisfactorily in language themselves. The challenge here lies in zooming out to the panoramic view, one that acknowledges multi- and inter-generational transmissions passed down the line in an array of acting-out behaviours and energetic interpersonal and cultural dynamics capable of communicating the affect bound to trauma without need of its linguistic record. Massumi describes such affect as intensity unqualified, not ownable or recognisable (by or to a given subject), casting emotion as intensity owned and recognised (by a given subject). ${ }^{37}$ I define traumatic affect in cyclical haunting as affect that bears the characteristics of trauma comprising both these forms of intensity, more or less distinctly or entwined on a circular, or feeding back and forth, continuum. 
It is worth mentioning that some propositions around the autonomy of affect I consider useful in regards to the transmission of trauma and the subsequent writing of it, have come in for harsh criticism, most notably from Ruth Leys, whose preoccupation with intention and signification favours a cognitivist inclination toward the operations of affect and emotion. ${ }^{38}$ I concede that intentionality and cognitive involvement are vital concerns regarding affect, and that both can play a role in transmission. I also have some sympathy for her concerns about responsibility and justice, but I see her claim that notions of autonomy necessarily conceptualise affects as 'inherently independent of meaning and intention' as problematic. ${ }^{39}$ It is not within the scope of this article to address her thorough evaluation further, suffice to say that though I think there is some merit in her critique of certain methodologies, I view her concluding position as too black and white. Leys's ultimate assertions foreclose complexities and potentials of affect and its operations that, unlikely to be wholly accounted for by intention and logic, warrant exploration, even if definitive scientific proof remains questionable. As I have demonstrated in my reading of Barker's Regeneraton Trilogy, bringing the theoretical filaments of hauntology and autonomy together enables the consideration of the autonomy of traumatic affect as cyclical assemblage, and by extension, the writing of it as political. This builds upon my assertion that traumatic affect operates as a social force that upsets assumptions of subjective containment, and that challenges and extends upon standard readings of certain texts.

So it is that in The Ghost Road, the final instalment, Barker ends the trilogy with a prime example of the feeding-forward and feeding-back loopings of cyclical haunting. Prior's structural/historical trauma in part informs his suicidal voluntary decision to return for a fourth tour in answer to the deathly call of the grave that is the Historical trauma of the trenches, where he is tragically killed in a futile battle only days before Armistice.

\section{-CONCLUSION}

The poetics of trans-trauma is literature that tells the stories and charts the topography of interlinkages and movements of intensities within assemblages inhabited by a given subject, family and society. This is what Barker attests to in the 
Regeneration Trilogy, her profoundly layered and epic witnessing to the cyclical haunting of war, both familial and nationalistic.

Inherent to my hypothesis is the claim that the poetics of trans-trauma is writing that witnesses and testifies to the transmission of traumatic affect and that as such it does the work of recognising traumatic gaps within the self and culture and reinstating life within those gaps through the acts of witnessing and living attention. Accepting this individual and artistic responsibility hardly absolves a writer from advocating or acting toward change in the social and political realm, but literature of this kind serves a crucial role in illuminating the structural and historic underpinnings of History and calling individuals to discernment. Such testimony is achieved not so much in prescriptive, literal, representational terms as by way of diverse affective and creative embodiments. Jill Bennett unwittingly describes the modus operandi of the poetics of trans-trauma when she says: 'The poetics of sense memory involve not so much speaking of but speaking out of a particular memory or experience-in other words, speaking from the body sustaining sensation.' 40 When Barker speaks in writing the Regeneration Trilogy, she speaks through her body and out of the memory of her culture and the spectres within it 'sustaining sensation.'

The focus on the familial transmission of trauma in these novels is key, since the family is the primary and frontline assemblage that links the subject to assemblages beyond, institutional, social, national and global. In the poetics of transtrauma, micro-macro traumatic memory is written as a ghostly presence and an affective feeding backward and forward. It is a creative process that converts distance-or the unknowability of trauma in the instance of its occurrence-into intensity artfully expressed in language. This is literature as a covert, yet formidable, form of political activism; until humanity adequately grasps the intimate connections between structural and formative subjective interpersonal experience and cultural and Historical assemblage the 'elaboration of more desirable social and political institutions and practices' LaCapra calls for cannot be made manifest.

Meera Atkinson is a Sydney-based writer, poet and scholar. Her writing has appeared in Salon.com, Meanjin, Best Australian Stories 2007, Best Australian Poems 
2010, Griffith REVIEW and The 2013 Voiceless Anthology, among other forums, and she co-edited Traumatic Affect (2013), a collection of essays exploring the nexus of trauma and affect. She completed a PhD via novel and dissertation on the transgenerational transmission and poetics of trauma at the University of Western Sydney.

-NOTES

1 Pat Barker, The Regeneration Trilogy, Penguin, Melbourne, 1999.

2 Sigmund Freud, in J. Strachey (ed.), New Introductory Lectures on Psychoanalysis, Hogarth Press, London, 1974, p. 315.

3 Jean Laplanche, Essays on Otherness, ed. John Fletcher, Routledge, London, 1999, p. 109.

4 Jacques Derrida, Specters of Marx, trans. Peggy Kamuf, Routledge, New York, 1994, p. 51.

5 Colin Davis, 'Hauntology, Spectres and Phantoms', French Studies, vol. 59, no. 3, 2005, pp. 373, 376.

6 Derrida, p. 39.

7 Melissa Gregg and Gregory J. Seigworth (eds), The Affect Theory Reader, Duke University Press, Durham, NC, 2010, pp. 6-8, p. 1.

8 Gilles Deleuze and Félix Guattari, $A$ Thousand Plateaus: Capitalism and Schizophrenia, The Athlone Press, London, 1988; Gilles Deleuze and Félix Guattari, 'Ethology: Spinoza and Us', in Jonathan Crary (ed.), Incorporations, Zone Books, New York, 1992, pp. 625-33; Brian Massumi, 'The Autonomy of Affect', in P. Patton (ed.), Deleuze: A Critical Reader, Blackwell, London, 1996, pp. 217-39; Brian Massumi, Parables for the Virtual: Movement, Affect, Sensation, Duke University Press, Durham, NC, 2002.

${ }^{9}$ Cathy Caruth, Unclaimed Experience: Trauma, Narrative, and History, Johns Hopkins University Press, Baltimore, 1996, p. 4; Alain Resnais (dir.), Hiroshima, Mon Amour, Argos Films, Como Films, Daiei Studios, Pathé Entertainment, 1959; Marguerite Duras, The Lover, trans. Barbara Bray, Harper Perennial, New York, 1992.

10 Barker, p. 90.

11 Massumi, Autonomy of Affect, p. 228.

12 Manuel De Landa, A New Philosophy of Society: Assemblage Theory and Social Complexity, Continuum, London, 2006.

13 Ibid., p. 3.

14 Ibid.

15 Ibid., p. 5.

16 Ibid., p. 4.

17 Ibid., p. 3. 
18 Ibid.

19 Ibid., p. 4.

20 Denise Riley, Impersonal Passion: Language as Affect, Duke University Press, Durham, NC, 2005;

Teresa Brennan, The Transmission of Affect, Cornell University Press, New York, 2004.

21 Riley, pp. 6, 16.

22 Allen Ginsberg, 'Howl', in Ann Charters (ed.), The Penguin Book of the Beats, Penguin Books, London, pp. 62-71.

23 Brennan, pp. 24, 94.

24 Barker, p. 106.

${ }^{25}$ John Fletcher, 'Introduction: Psychoanalysis and the Question of the Other', in Jean Laplanche, Essays on Otherness, ed. John Fletcher, Routledge, London, 1999, p. 10.

${ }^{26}$ Laplanche, p. 109.

27 Ibid.

28 Dominick LaCapra, 'Trauma, Absence, Loss', Critical Inquiry, vol. 25, no. 4, pp. 696-727, 722.

${ }^{29}$ Ibid., p. 722.

30 Ibid.

31 LaCapra, p. 727.

32 Barker, p. 238.

33 Ibid.

34 Ibid., p. 45.

35 Brennan, p. 24.

36 Massumi, Parables for the Virtual, p. 12.

37 Massumi, 'Autonomy of Affect', p. 221.

${ }^{38}$ Ruth Leys, 'The Turn to Affect: A Critique', Critical Inquiry, vol. 37, no. 3, pp. 434-72.

39 Ibid., p. 450.

40 Jill Bennett, Empathic Vision: Affect, Trauma, and Contemporary Art, Stanford University Press, Stanford, CA, 2005, p. 38.

\section{-BIBLIOGRAPHY}

Barker, P., The Regeneration Trilogy, Penguin, Melbourne, 1999.

Bennett, J., Empathic Vision: Affect, Trauma, and Contemporary Art, Stanford University Press, Stanford, CA, 2005.

Brennan, T., The Transmission of Affect, Cornell University Press, New York, 2004.

Caruth, C., Unclaimed Experience: Trauma, Narrative, and History, Johns Hopkins University Press, Baltimore, 1996.

Charters, A. (ed.), The Penguin Book of the Beats, Penguin Books, London. 
Davis, C., 'Hauntology, Spectres and Phantoms', French Studies, vol. 59, no. 3, 2005. doi: http://dx.doi.org/10.1093/fs/kni143

De Landa, M., A New Philosophy of Society: Assemblage Theory and Social Complexity, Continuum, London, 2006.

Deleuze, G. and F. Guattari, 'Ethology: Spinoza and Us', in J. Crary (ed.), Incorporations, Zone Books, New York, 1992.

Deleuze, G. and F. Guattari, $A$ Thousand Plateaus: Capitalism and Schizophrenia, The Athlone Press, London, 1988.

Derrida, J., Specters of Marx, trans. P. Kamuf, Routledge, New York, 1994.

Duras, M., The Lover, trans. B. Bray, Harper Perennial, New York, 1992.

Fletcher, J., 'Introduction: Psychoanalysis and the Question of the Other', in J. Laplanche, Essays on Otherness, ed. J. Fletcher, Routledge, London, 1999.

Ginsberg, A., 'Howl', in A. Charters (ed.), The Penguin Book of the Beats, Penguin Books, London.

Gregg M. and G.J. Seigworth (eds), The Affect Theory Reader, Duke University Press, Durham, NC, 2010.

LaCapra, D., 'Trauma, Absence, Loss', Critical Inquiry, vol. 25, no. 4. doi: http://dx.doi.org/10.1086/448943

Laplanche, J., Essays on Otherness, ed. J. Fletcher, Routledge, London, 1999.

Leys, R., 'The Turn to Affect: A Critique', Critical Inquiry, vol. 37, no. 3. doi: http://dx.doi.org/10.1086/659353

Massumi, B., 'The Autonomy of Affect', in P. Patton (ed.), Deleuze: A Critical Reader, Blackwell, London, 1996.

Massumi, B., Parables for the Virtual: Movement, Affect, Sensation, Duke University Press, Durham, NC, 2002. doi: http://dx.doi.org/10.1215/9780822383574

Riley, D., Impersonal Passion: Language as Affect, Duke University Press, Durham, NC, 2005. doi: http://dx.doi.org/10.1215/9780822386780

Strachey, J. (ed.), New Introductory Lectures on Psychoanalysis, Hogarth Press, London, 1974.

-FILMS

Resnais, A., (dir.), Hiroshima, Mon Amour, Argos Films, Como Films, Daiei Studios, Pathé Entertainment, 1959. 